Diabetologia 9, 509-513 (1973)

(C) by Springer-Verlag 1973

\title{
The Nature of the Artifactual Synalbumin Insulin Antagonist
}

\author{
G.N. Holcomb and W.E. Dulin \\ Department of Medicinal Chemistry Ferris State College, Big Rapids, Michigan 49307, U.S.A. and Diabetes and \\ Atherosclerosis Research, The Upjohn Company, Kalamazoo, Michigan 49001, U.S.A.
}

Received: May 2, 1973, and in revised form: July 31, 1973

\begin{abstract}
Summary. The levels of insulin antagonism exhibited by human plasma albumin samples extracted by the alcoholic-trichloroacetic acid (TCA) method were found to vary over a wide range. Similar variations were found in the chlorine contents of these albumin samples, thus indicating a variation in TCA content. Chlorine content correlated with the levels of antagnonism exhibited by the various samples. Both chlorine levels and antagonistic activity were reduced appreciably by chromatography with Dowex 50W ion exchange resin. When Dowex treated (nonantagonistic) albumin was dissolved in water and re-extracted by the TCA-ethanol method, the resulting albumin preparations were high in chlorine content
\end{abstract}

and highly antagonistic toward insulin. Nonantagonistic albumin was rendered antagonistic by the addition of TCA. The levels of antagonism exhibited by the TCA treated albumin preparations correlated with their chlorine contents. It is concluded that at least a portion of the insulin inhibitory effects exhibited by albumin preparations isolated by the TCA-ethanol method is due to TCA which is bound to the protein.

Key words: Diabetes mellitus, insulin antagonism, synalbumin, trichloroacetic acid, plasma albumin, rat diaphragm, artifactual insulin antagonist.
In 1961, Vallance-Owen proposed that the primary abnormality in essential diabetes could be increased antagonism to insulin as evidenced by increased levels of the synalbumin insulin antagonist [1]. Considerable research has been conducted on synalbumin. However, the role (if any) which it occupies in the pathogenesis of diabetes has not been determined. One of the major difficulties encountered in attempting to determine the significance of this insulin antagonist in diabetes is the conflicting results obtained by different investigators $[2,3]$.

A number of workers have confirmed VallanceOwen's observation that human plasma albumin or something associated with it antagonizes the effects of insulin on glucose uptake by the rat hemidiaphragm [4-13]. Others, however, have been unable to detect insulin antagonism in human albumin, but instead have found insulin-like activity (ILA) [14, 15]. Still others have found both ILA and anti-insulin activity in human albumin preparations $[16,17]$. There is also disagreement regarding the quantitative aspects of insulin antagonism exhibited by plasma albumin $[2,3$, 18]. Mirsky, in fact, has recently reported that in studies on over 200 subjects, essentially the same synalbumin levels were found in the plasmas of nondiabetic and diabetic populations [19].

The precise reasons for the conflicting results obtained by different investigators are not known, but it seems quite likely that they could be related to the procedures used to extract and purify the albumin. For the most part, Vallance-Owen has used a modification [18] of the acid-ethanol extraction method of Debro and associates [20] for isolating albumin. Most other workers have also employed this method of isolation [2]. Ensinck and associates [16] reported that an artifactual insulin antagonist is extracted along with albumin when the trichloroacetic acid (TCA)ethanol extraction procedure is employed. They proposed that this substance was derived from the Visking dialysis tubing. We have previously reported that Debro isolated albumin contains an artifactual insulin antagonist, but our data do not support the conclusion that this substance is derived from the dialysis membranes [13].

A number of possibilities exist regarding the nature and origin of the artifactual insulin antagonist associated with Debro extracted albumin [13]. The results of preliminary experiments conducted in our laboratories led us to believe that TCA or a TCA-protein complex could be the artifactual insulin antagonist present in these preparations [21]. The present studies were conducted to gain further information on the nature of the artifactual insulin antagonist extracted by the Debro procedure.

\section{Materials and Methods}

\section{Isolation of Human Plasma Albumin}

Plasma was extracted with TCA-ethanol according to the procedure of Debro and associates [20] as modified by Vallance-Owen et al. [18]. One liter of $10 \%$ aqueous TCA was added to one liter of outdated human plasma to precipitate the plasma proteins. The mixture was centrifuged and the supernatant was discarded. The precipitated proteins were suspended in one liter of $5 \%$ aqueous TCA and the mixture was centrifuged. The supernatant was discarded and three liters of $1 \%$ TCA in ethanol was added to the precipitate. The mixture was stirred for $15 \mathrm{~min}$ at $4^{\circ}$ to extract the albumin. 
The mixture was centrifuged and the supernatant was dialyzed against distilled water (10 l) at $4^{\circ}$ for $72 \mathrm{~h}$. The dialysis water was changed four times daily. Boiled Visking casings $(60 \mathrm{~cm}, 27 / 32)$ were used for the dialysis. The retentate was centrifuged to remove denatured protein and the supernatant was lyophilized.

\section{Nonantagonistic Albumin}

Human plasma albumin was rendered nonantagonistic by Dowex chromatography as described by Ensinck et al. [4]. Ten grams of albumin were dissolved in $200 \mathrm{ml}$ of $0.15 \mathrm{M}$ sodium chloride and the solution was applied to a $5 \times 85 \mathrm{~cm}$ column of Dowex $50 \mathrm{~W} \mathrm{S-8}$ 200-400 mesh in the sodium form and the sample was eluted with $0.15 \mathrm{M}$ sodium chloride. The fractions containing the albumin were pooled and dialyzed as described above. The retentate was centrifuged and lyophilized.

\section{Re-extraction of Albumin}

Ten grams of nonantagonistic albumin were dissolved in $200 \mathrm{ml}$ of distilled water and the solution was extracted, dialyzed, and lyophilized as described for the isolation of albumin from human plasma.

\section{Addition of TCA to Nonantagonistic Albumin}

Three grams of nonantagonistic albumin were dissolved in $50 \mathrm{ml}$ of water containing a previously calculated volume of $1.6 \%$ TCA $(0-16 \mathrm{ml})$. The solution was stirred at $4^{\circ}$ for $30 \mathrm{~min}$ and lyophilized.

\section{Hemidiaphragm Assay}

The rat hemidiaphragm assay [1] was used to measure insulin antagonism. Rats used as donors of hemidiaphragms were Upjohn pathogen free rats weighing 100-130 g. Insulin concentration was based on the dose-response curve, i.e. the lowest concentration giving a maximum response. Concentrations ranged from $300-500$ microunits per milliliter. The hemidiaphragms were placed in vials fitted with rubber stoppers and incubated at $37^{\circ}$ for $90 \mathrm{~min}$ in a Dubnoff metabolic shaker. The incubation medium in each vial was gassed with $95 \%$ oxygen $-5 \%$ carbon dioxide for one minute immediately before the hemidiaphragm was added. The vials were then closed, gassed for an additional $5 \mathrm{~min}$, and incubated. Medium glucose concentrations were determined with an Autoanalyzer.

\section{Chlorine Analysis}

Chlorine contents of albumin samples were determined by the method of Olson and Krivis [22].

\section{Results}

Some, but not all, of the randomly selected Debro albumin samples reported in Table 1 antagonized the effects of insulin in the rat hemidiaphragm assay. The degree of antagonism exhibited by the various samples correlated with their relative chlorine content, which was used as an indicator of their TCA content. The Cohn fraction $V$ albumin preparation which was studied was low in chlorine content and did not antagonize insulin in rat muscle in vitro.

Albumin was rendered nonantagonistic by ion exchange chromatography with Dowex $50 \mathrm{~W}$ resin (Table 2). These nonantagonistic albumin preparations contained less than $1 \%$ chlorine, thus indicating a low ICA content.

Nonantagonistic albumin became antagonistic when it was reextracted from aqueous solution with TCAethanol, dialyzed, and lyophilized (Table 3). The chlorine contents of these samples were high, thus indicating a high TCA content.

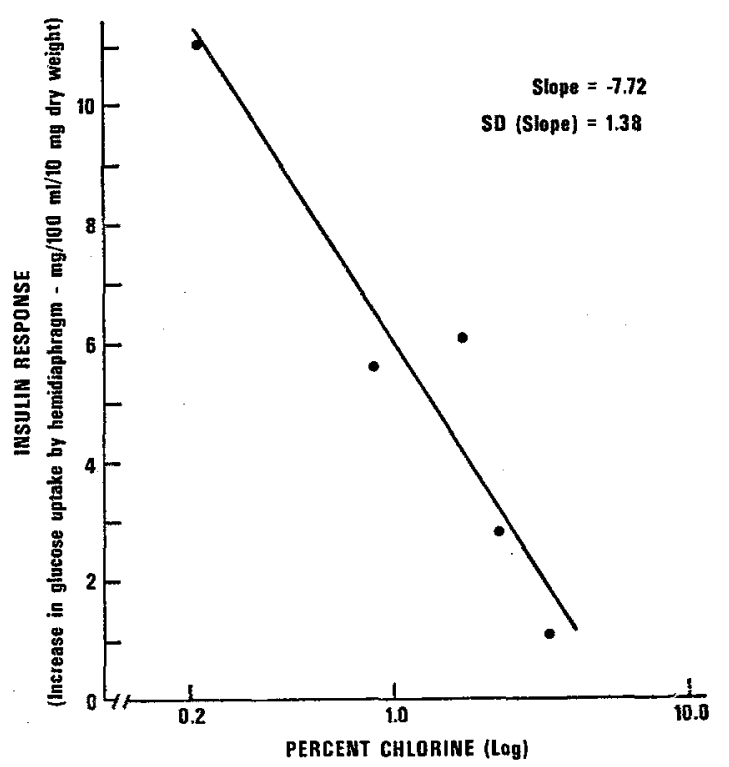

Fig. 1. Correlation of insulin response and chlorine content of TCA treated albumin preparations. Each point represents the average of the values obtained from three or four hemidiaphragms

Nonantagonistic albumin was rendered antagonistic by the addition of varying quantities of TCA (Table 4). The degree of antagonism in the various samples correlated with their respective chlorine (TCA) contents. The correlation between insulin inhibitory effect and chlorine content in a number of TCA treated albumin preparations is illustrated in Fig. 1 .

\section{Discussion}

It is apparent from the data reported in this paper and elsewhere $[8,13,16]$ that at least some of the insulin antagonism exhibited by Debro isolated plasma albumin is due to the presence of an artifactual insulin antagonist. This artifactual antagonist could explain some of the discrepancies which exist regarding the 
Table 1. Effect of various albumin preparations on insulin stimulation of glucose uptake by the rat hemidiaphragm ${ }^{\mathrm{a}}$

\begin{tabular}{|c|c|c|c|c|c|c|c|}
\hline \multirow{2}{*}{$\begin{array}{l}\text { Albumin } \\
\text { preparation }\end{array}$} & \multirow{2}{*}{$\begin{array}{l}\text { Per cent } \\
\text { chlorine }\end{array}$} & \multirow{2}{*}{$\begin{array}{l}\text { No. of hemi- } \\
\text { diaphragms } \\
\text { for testing }\end{array}$} & \multicolumn{4}{|c|}{ Glucose uptake $\left(\mathrm{mg} / 100 \mathrm{ml} / 10 \mathrm{mg}\right.$ dry wt) $\pm \mathrm{SE}^{\mathrm{b}}$} & \multirow{2}{*}{$\begin{array}{l}\text { Level of } \\
\text { antagonism }\end{array}$} \\
\hline & & & B & $\mathbf{I}$ & A & $A+I$ & \\
\hline Cohn Fr. V & 0.14 & 7 & $13.0 \pm 0.82$ & $20.9 \pm 1.57$ & $11.8 \pm 0.66$ & $21.7 \pm 2.02$ & $\operatorname{NS}^{\mathrm{d}}$ \\
\hline Debro & 0.86 & 3 & $7.4 \pm 0.32$ & $17.1 \pm 0.81$ & $8.8 \pm 0.45$ & $15.6 \pm 0.98$ & NS \\
\hline Debro & 1.36 & 3 & $8.0 \pm 0.29$ & $16.4 \pm 0.90$ & $5.8 \pm 0.48$ & $18.8 \pm 0.54$ & NS \\
\hline Debro & 1.68 & 8 & $12.4 \pm 0.29$ & $23.1 \pm 0.71$ & $13.3 \pm 0.48$ & $18.3 \pm 1.01$ & $p<0.01$ \\
\hline Debro & 4.14 & $\mathbf{3}$ & $5.7 \pm 0.46$ & $19.2 \pm 0.93$ & $9.6 \pm 1.26$ & $13.3 \pm 0.52$ & $p<0.01$ \\
\hline Debro & 4.62 & 9 & $9.5 \pm 1.04$ & $20.5 \pm 1.21$ & $12.4 \pm 0.87$ & $15.2 \pm 0.99$ & $p<0.01$ \\
\hline Debro & 5.13 & 4 & $16.4 \pm 0.90$ & $22.6 \pm 1.10$ & $16.6 \pm 0.42$ & $17.9 \pm 0.96$ & $p<0.05$ \\
\hline Debro & 5.21 & 4 & $16.9 \pm 1.15$ & $25.3 \pm 0.06$ & $15.0 \pm 0.58$ & $13.6 \pm 0.78$ & $p<0.01$ \\
\hline
\end{tabular}

a Abbrev.: $B=$ buffer; $\mathrm{I}=$ insulin; and $\mathrm{A}=$ albumin

b Standard error of the mean.

c Difference between insulin effect without albumin $(\mathrm{I}-\mathrm{B})$ and insulin effect with albumin $[(\mathrm{A}+\mathrm{I})-\mathrm{A}]$.

d Not significant.

Statistical analysis of the data were done by analysis of variance [34].

Table 2. Effect of Dowex treated albumin preparations on insulin stimulation of glucose uptake by the rat hemidiaphragm ${ }^{\mathrm{a}}$

\begin{tabular}{|c|c|c|c|c|c|c|c|}
\hline \multirow{2}{*}{$\begin{array}{l}\text { Albumin } \\
\text { preparation }\end{array}$} & \multirow{2}{*}{$\begin{array}{l}\text { Per cent } \\
\text { chlorine }\end{array}$} & \multirow{2}{*}{$\begin{array}{l}\text { No. of hemi- } \\
\text { diaphragms } \\
\text { for testing }\end{array}$} & \multicolumn{4}{|c|}{ Glucose uptake $\left(\mathrm{mg} / 100 \mathrm{ml} / 10 \mathrm{mg}\right.$ dry wt) $\pm \mathrm{SE}^{\mathrm{b}}$} & \multirow{2}{*}{$\begin{array}{l}\text { Level of } \\
\text { antagonism }\end{array}$} \\
\hline & & & $\mathbf{B}$ & $\mathbf{I}$ & A & $A+I$ & \\
\hline$\overline{\mathrm{A}}$ & 0.39 & 7 & $13.7+0.51$ & $22.5+1.11$ & $13.5+0.78$ & $22.15+1.01$ & $\mathrm{NS}^{\mathrm{d}}$ \\
\hline B & 0.45 & 4 & $13.7 \pm 1.13$ & $19.9 \pm 0.12$ & $10.6 \pm 0.46$ & $19.2 \pm 0.55$ & NS \\
\hline $\mathrm{C}$ & 0.52 & $\overrightarrow{3}$ & $10.8 \pm 1.62$ & $24.5 \pm 1.67$ & $9.3 \pm 0.05$ & $20.1 \pm 0.83$ & NS \\
\hline
\end{tabular}

a Abbrev.: $\mathrm{B}=$ buffer ; $\mathrm{I}=$ insulin; and $\mathrm{A}=$ albumin.

b Standard error of the mean.

c Difference between insulin effect without albumin $(\mathrm{I}-\mathrm{B})$ and insulin effect with albumin $[(\mathrm{A}+\mathrm{I})-\mathrm{A}]$.

d Not significant. Statistical analysis of the data were done by analysis of variance [34].

Table 3. Effect of re-extracted albumin preparations on insulin stimulation of glucose uptake by the rat hemidiaphragm ${ }^{\text {a }}$

\begin{tabular}{|c|c|c|c|c|c|c|c|c|}
\hline \multirow{2}{*}{$\begin{array}{l}\text { Albumin } \\
\text { preparation }\end{array}$} & \multirow{2}{*}{$\begin{array}{l}\text { Per cent } \\
\text { chlorine } \\
\text { before } \\
\text { re-ex- } \\
\text { traction }\end{array}$} & \multirow{2}{*}{$\begin{array}{l}\text { Per cent } \\
\text { chlorine } \\
\text { after } \\
\text { re-ex. } \\
\text { traction }\end{array}$} & \multirow{2}{*}{$\begin{array}{l}\text { No. of hemi- } \\
\text { diaphragms } \\
\text { for testing }\end{array}$} & \multicolumn{4}{|c|}{ Glucose uptake $\left(\mathrm{mg} / 100 \mathrm{ml} / 10 \mathrm{mg}\right.$ dry wt) $\pm \mathrm{SE}^{b}$} & \multirow{2}{*}{$\begin{array}{l}\text { Level of } \\
\text { antagonism }\end{array}$} \\
\hline & & & & $\mathbf{B}$ & $\mathbf{I}$ & $A$ & $A+I$ & \\
\hline$\overline{\mathrm{A}}$ & 0.20 & 2.39 & 6 & $11.9 \pm 0.66$ & $22.5 \pm 0.84$ & $10.0 \pm 0.70$ & $13.6 \pm 1.03$ & $p<0.01$ \\
\hline$B$ & 0.14 & 4.73 & 3 & $6.7 \pm 0.59$ & $17.4 \pm 0.62$ & $11.2 \pm 0.62$ & $12.5 \pm 0.67$ & $p<0.01$ \\
\hline $\mathrm{C}$ & 0.32 & 2.48 & 6 & $11.9 \pm 0.66$ & $22.5 \pm 0.84$ & $11.0 \pm 0.70$ & $13.0 \pm 0.92$ & $p<0.01$ \\
\hline
\end{tabular}

a Abbrev.: $\mathrm{B}=$ buffer; $\mathrm{I}=$ insulin; and $\mathrm{A}=$ albumin.

b Standard error of the mean.

c Difference between insulin effect without albumin $(\mathbf{I}-\mathbf{B})$ and Insulin effect with albumin $[(A+\mathbf{I})-\mathrm{A}]$. Statistical analysis of the data were done by analysis of variance [34].

Table 4. Effect of TCA treated albumin preparations on insulin stimulation of glucose uptake by the rat hemidiaphragma

\begin{tabular}{|c|c|c|c|c|c|c|c|}
\hline \multirow{2}{*}{$\begin{array}{l}\text { Albumin } \\
\text { preparation }\end{array}$} & \multirow{2}{*}{$\begin{array}{l}\text { Per cent } \\
\text { chlorine }\end{array}$} & \multirow{2}{*}{$\begin{array}{l}\text { No. of hemi- } \\
\text { diaphragms } \\
\text { for testing }\end{array}$} & \multicolumn{4}{|c|}{ Glucose uptake $\left(\mathrm{mg} / 100 \mathrm{ml} / 10 \mathrm{mg}\right.$ dry wt) $\pm \mathrm{SE}^{\mathrm{b}}$} & \multirow{2}{*}{$\begin{array}{l}\text { Level of } \\
\text { antagonism }\end{array}$} \\
\hline & & & A & $A+I$ & $A^{\prime}$ & $A^{\prime}+I$ & \\
\hline $\bar{A}$ & 0.49 & 6 & $7.9 \pm 0.67$ & $16.2 \pm 0.94$ & $10.3 \pm 0.67$ & $18.4 \pm 1.18$ & $\mathrm{NS}^{\mathrm{d}}$ \\
\hline B & 1.12 & $\mathbf{3}$ & $6.3 \pm 0.41$ & $18.5 \pm 1.36$ & $7.2 \pm 0.61$ & $15.6 \pm 2.43$ & NS \\
\hline $\mathrm{C}$ & 1.22 & 6 & \pm 0.67 & $16.2 \pm 0.94$ & $9.4 \pm 0.87$ & $14.6 \pm 1.00$ & NS \\
\hline $\mathrm{D}$ & 1.67 & 3 & $7.9 \pm 0.67$ & $16.2 \pm 0.94$ & $8.6 \pm 0.65$ & $15.2 \pm 0.91$ & NS \\
\hline $\mathbf{E}$ & 1.69 & 6 & $7.9 \div 0.67$ & $16.2 \pm 0.94$ & $8.9 \mp 0.66$ & $15.9 \pm 1.00$ & NS \\
\hline $\mathrm{F}$ & 2.43 & 3 & $6.9 \pm 0.95$ & $20.9 \pm 2.09$ & $7.6 \pm 0.53$ & $14.1 \pm 1.33$ & $p<0.05$ \\
\hline G & 2.71 & 6 & $11.2 \pm 0.45$ & $19.1 \pm 0.76$ & $8.1 \pm 0.38$ & $11.9=0.77$ & $p<0.01$ \\
\hline H & 3.42 & 3 & $7.1 \pm 0.55$ & $17.3 \pm 0.26$ & $6.4 \pm 0.57$ & $10.0 \pm 0.81$ & $p<0.01$ \\
\hline I & 3.51 & 6 & $11.2 \pm 0.45$ & $19.1 \pm 0.76$ & $8.3 \pm 0.36$ & $10.6 \pm 0.40$ & $p<0.01$ \\
\hline
\end{tabular}

a Abbrev.: $\mathrm{I}=$ insulin; $A=$ Dowex treated (nonantagonistic) albumin; $A^{\prime}=$ TCA treated albumin,

b Standard error of the mean.

c Difference between insulin effect with Dowex treated albumin $[(A+I)-A]$ and insulin effect with TCA treated albumin $\left[\left(A^{\prime}+I\right)-A^{\prime}\right]$.

d Not significant. 
presence or absence of elevated levels of the synalbumin insulin antagonist in the plasma of diabetics $[2,3]$. It could also explain the random variations in levels of insulin antagonism observed by Mirsky in his studies with large groups of diabetic and nondiabetic subjects [23.]

Differences in the ability to demonstrate elevated synalbumin levels in diabetics could result from minor variations in the procedure used to isolate the albumin. These variations could influence the amount of artifactual antagonist present in different albumin samples. This contention is supported by the observation [21] that two albumin preparations which were prepared by exactly the same procedures from identical starting materials, but at different times, showed wide variations in degree of antagonism.

The conditions used to dialyze the TCA and ethanol from albumin are of particular interest in regard to sample variations. It is known that a number of factors can affect dialysis rate and also determine which materials are dialyzable. Among these are $\mathrm{pH}$, ionic strength, temperature, membrane porosity, dimensions of dialysis casings, volume of water, and frequency of water changes [24]. Any or all of these factors could have a profound influence on the nature and quantities of materials retained with albumin during dialysis.

It has been suggested [16] that the artifactual insulin antagonist associated with Debro albumin could be a material extracted from Visking tubing during dialysis. Studies conducted in our laboratories, however, indicate that it is unlikely that a constituent extracted from dialysis membranes could account for the insulin inhibitory effects of these albumin preparations [13].

A second factor that might be uncontrollable by the dialysis methods used, and therefore produce an artifactual antagonist, is TCA. Evidence to support the hypothesis that TCA may be a factor in the sample to sample variations in albumin preparations is provided by reports $[8,10,12]$ that some antagonistic albumin preparations cause a significant decrease in the $\mathrm{pH}$ of Krebs-Ringer bicarbonate buffer and that the antagonistic effect of these albumin preparations is attenuated after $\mathrm{pH}$ adjustment $[8,12]$. Further evidence to support this hypothesis is:

1. The Debro albumin preparations which were investigated in these studies varied over a wide range with respect to chlorine (TCA) contents $(0.86-5.29 \%$ chlorine). Samples containing less than $1.68 \%$ chlorine did not exhibit significant antagonism whereas those containing greater than $1.68 \%$ chlorine were highly antagonistic.

2. Debro albumin was rendered nonantagonistic by ion exchange chromatography with Dowex $50 \mathrm{~W}$ ion exchange resin in the sodium form. Any portion of the albumin sample having large amounts of TCA bound to it would carry a net positive charge and would be expected to be retained by the resin. The fact that the chlorine content of the samples decreased substantially after Dowex chromatography indicates that this did occur.

3. Re-extraction of nonantagonistic albumin from aqueous solution by the Debro procedure resulted in albumin preparations which were highly antagonistic toward insulin and also high in chlorine and TCA content (2.39-4.73\% chlorine).

4. Nonantagonistic albumin was rendered antagonistic by the addition of TCA. The degree of antagonism exhibited by these preparations correlated with the amount of TCA added and with the relative chlorine contents.

The relationship between chlorine content and insulin antagonism was found to be comparable for Debro, Dowex treated, re-extracted, and TCA treated albumin preparations. It should be noted, however, that two of the TCA treated albumin preparations containing approximately $1.7 \%$ chlorine did not exhibit significant antagonism whereas one of the Debro albumin preparations containing $1.68 \%$ chlorine did exhibit significant antagonism. The antagonism exhibited by the Debro albumin sample was far from complete, but because of the comparatively large number of hemidiaphragms tested and the relatively small standard errors incurred in the assays, the results were statistically significant $(p<0.01)$. This is most likely the borderline area for the amount of chlorine (TCA) necessary to cause antagonism.

The binding of TCA to human plasma albumin would be expected because of the physical and chemical properties of these molecules $[25,26,27]$. TCA would presumably bind primarily to basic groups of lysine and arginine residues, but it could also bind to histidine and tryptophan residues [27, 28]. Based on the molecular weight [25] and amino acid composition [29] of plasma albumin, the protein could theoretically bind sufficient TCA to correspond to $10.8 \%$ chlorine (16.6\% TCA), even if TCA were bound only to lysine and arginine residues. Accordingly, the chlorine (TCA) levels found in the albumin samples used in these studies fall within a reasonable range. Variations in dialysis conditions could account for the sample to sample variations in chlorine (TCA) content and, hence, in insulin inhibitory activity.

The results of the studies reported here further confirm the presence of an artifactual insulin antagonist associated with Debro isolated plasma albumin. Moreover, these studies provide evidence to indicate that at least some of the antagonism associated with Debro albumin is caused by TCA or a TCA-protein complex which is not completely removed during dialysis. These studies do not, however, preclude the possibility that a physiological insulin antagonist could be associated with plasma albumin. Other methodology will be required to establish the existence of a physiological antagonist.

Evidence which has previously been cited in support of a physiological insulin antagonist is that albumin preparations dialyzed in essentially neutral solu- 
tions or not dialyzed at all have been found to be antagonistic. Recent investigations in Vallance-Owen's laboratory $[30,31]$ have been conducted with albumin preparations isolated by the method of Fernandez et al. [32], a procedure requiring neither TCA nor dialysis. Albumin isolated from serum in this manner was found to be antagonistic in 27 of 30 diabetics and in only 4 of 22 control subjects [33].

Admittedly, TCA could not be an artifactual antagonist in these albumin preparations, however, there is no evidence to rule out the possibility that other artifactual insulin antagonists could be present. A number of substances are known to bind to plasma albumin [25] and some of those could contribute to its antagonistic properties. Accordingly, it seems important to determine whether artifactual insulin antagonists are present in albumin preparations isolated by methods other than the Debro procedure.

Acknowledgement. We thank Mr. Thomas J. Silhavy for technical assistance, Mrs. Beatrice M. Wyse for the hemidiaphragm assays, Dr. John Schultz for statistical analysis, and $\mathrm{Mr}$. Norman Knight for the chlorine assays. This research was supported in part by a research grant from the U.S. Public Health Service, Institute of Arthritis and Metabolic Diseases (AM-10997-01).

\section{References}

1. Vallance-Owen, J., Lilley, M.D.: Insulin antagonism in the plasma of obese diabetics and prediabetics. Lancet $1961 \mathrm{I}, 806-807$

2. Davidson, M.B., Poffenbarger, P.L.: Role of synalbumin insulin antagonist in pathogenesis of diabetes mellitus. Metabolism 19, 668-686 (1970)

3. Berson, S.A., Yalow, R.S.: In: Diabetes Mellitus: Theory and practice, (Ellenberg, M., Rifkin, H., eds.) pp. 391-396. New York: McGraw-Hill 1970

4. Ensinck, J.W., Mahler, R.J., Vallance-Owen, J.: Antagonism of insulin action on muscle by the albumin-bound B chain of insulin. Biochem. J. 94, 150-159 (1965)

5. Alp, H., Recant, L. : Studies of the insulin-inhibitory effect of human albumin fractions. J. clin. Invest. 44, $870-882(1965)$

6. Davidson, M.B., Goodner, C.J.: Assay of insulin antagonism by serial incubation of paired rat hemidiaphragms. Diabetes 15, 380-387 (1966)

7. Sherman, L.: The Vallance-Owen ("synalbumin") insulin antagonist. Diabetes 15, 149-159 (1966)

8. Buse, M. G., McMaster, B.S., Buse J.: Effect of human serum albumin on the glucose metabolism of isolated rat diaphragm and its response to insulin. Diabetes 15, $388-398(1966)$

9. Ehrlich, R.M., Martin, J.M. : Presence of synalbumin insulin antagonist in siblings of diabetic children. Diabetes 15, 400-405 (1966)

10. Mahler, R.J., Szabo, O.: Effects of normal hurnan albumin upon glucose uptake by the isolated rat diaphragm in the prosence and absence of insulin. Metabolism 16, 853-864 (1967)

11. Lowy, C., Blanshard, G., Phear, D.: Antagonism of insulin by albumin. Lancet 1961 I, $802-804$

12. Jervell, J.: The antagonistic effect of human albumin on the insulin stimulated glucose uptake of the isolated rat diaphragm. Acta physiol. Scand. 65, 33-44 (1965)
13. Holcomb, G.N., Dulin, W.E.: Studies on the nature of the synalbumin insulin antagonist. Proc. Soc. exp. Biol. Med. 128, 154-157 (1968)

14. Keen, H. : Properties of human "albumin". Diabetes $12,406-413$ (1963)

15. Cameron, J.S., Keen, H., Menzinger, G.: Insulin activity of normal plasma and plasma acid-ethanol extracts. Lancet 1964 I, 74-76

16. Ensinck, J.W., Poffonbarger, P.L., Hogan, R.A., Williams, R.H.: Studies on insulin antagonism, An artifactual antagonist to insulin and plasma nonsuppressible insulin-like activity occurring in preparation of "albumin". Diabetes 16, 289-301 (1967)

17. Arvill, A., Westberg, G., Jonsson, K. A., Hood, B., Ahren, K.: Insulin-like activity and insulin-inhibitory effect of human albumin fractions studied with two biological test methods. Diabetologia 2, 253-259 (1966)

18. Vallance-Owen, J., Dennes, E., Campbell, N.: Insulin antagonism in plasma of diabetic patients and normal subjects. Lancet $\mathbf{1 9 5 8}$ II, $336-339$

19. Mirsky, I.A.: In: Diabetes Mellitus: Theory and practice, (Ellenberg, M., Rifkin, H., eds.), p. 999. New York: MeGraw-Hill 1970

20. Debro, J.R., Tarver, A.B., Korner, A.: The determination of serum albumin and globulin by a new method. J. Lab. clin. Med. 50, 728-732 (1957)

21. Dulin, W.E.: In : Early diabetes, (Camerini-Davalos, R., Cole, H.S., eds.), p. 187. New York: Academic Press 1970

22. Olson, F.C., Krivis, A.F.: Determination of chlorine in organic compounds. Microchemical Journal 4, $181-$ $186(1960)$

23. Mirsky, I. A., Personal Communication

24. Craig, L.C., King, T.P.: In: Methods of biochemical analysis, Vol. 10, (Glick, D., ed.), pp. 175-199. New York: Interscience 1962

25. Putnam, F.W.: In: The proteins, Vol. 3, (Neurath, H., ed.), Chapter 14. New York: Acadomic Press 1965

26. Albert, A., Serjeant, E.P.: Ionization constants at acids and bases, p. 124. New York: Wiley 1962

27. Lehninger, A.L.: Biochemistry, p. 74. New York: Worth 1970

28. Swaney, J.B., Klotz, I.M.: Amino acid sequence adjoining the lone tryptophan of human serum albumin. A binding site of the protein. Biochemistry 9, $2570-2574(1970)$

29. Franglen, G., Swaniker, G.R.E.: Preparation and analysis of peptide fragments produced by pepsin hydrolysis of human plasma albumin and their relation to its structure. Biochem. J. 109, 107-120 (1968)

30. Bajaj, J.S., Vallance-Owen, J.: Variations in synalbumin insulin antagonism during tolbutamide tolerance test. Diabetologia 7, 133-135 (1971)

31. Bajaj, J.S., McMaster, D., Vallance-Owen, J.: Further studies on the incidence of the synalbumin insulin antagonist. Diabetologia 7, 136-138 (1971)

32. Fernandez, A., Sobel, C., Goldenberg, H.: Improved method for determination of serum albumin and globulin. Clin. Chem. 12, 194-205 (1966)

33. Vallance-Owen, J., McMaster, D.: Serum albumin and insulin antagonism. Lancet $\mathbf{1 9 6 8}$ II, 1192-1193

34. Snedecor, G.W.: Statistical Methods, p. 85. Ames, Iowa: Iowa State University Press 1962

Dr. W.E. Dulin

Diabetes and Atherosclerosis Research

The Upjohn Company

Kalamazoo

Michigan 49001

U.S.A. 